\title{
4
}

Paweł Drapikowski

Politechnika Poznańska

Joanna Wesołowska

Volkswagen Poznań Sp. z o.o.

http://dx.doi.org/10.18778/8088-905-7.05

\section{Studia dualne w Politechnice Poznańskiej - program i doświadczenia}

\section{Geneza}

Studia dualne to połączenie teorii i praktyki. Teorii uczą się studenci $\mathrm{w}$ murach uczelni, a praktykę zdobywają w przedsiębiorstwach już w trakcie studiów. Najczęściej po zakończeniu studiów są $w$ tych przedsiębiorstwach zatrudniani.

$\mathrm{Z}$ inicjatywą kształcenia $\mathrm{w}$ trybie dualnym na kierunku automatyka i robotyka w Politechnice Poznańskiej wystąpiło przedsiębiorstwo Phoenix Contact Wielkopolska Sp. z o.o. z siedzibą w Nowym Tomyślu. Pomysł podchwyciła firma Volkswagen Poznań i w połowie 2011 r. rozpoczęły się prace organizacyjne. Obydwie firmy prowadzą studia dualne na terenie Niemiec, gdzie taki rodzaj kształcenia realizowany jest od kilkunastu lat. 


\section{Cele i założenia}

Głównym celem studiów dualnych jest skrócenie okresu adaptacji zawodowej i przygotowanie studentów do wykonywania zadań $\mathrm{w}$ pełnym zakresie na danym stanowisku zaraz po zakończeniu studiów. Prace $\mathrm{w}$ działach utrzymania ruchu, prace projektowo-konstrukcyjne oraz związane z modernizacją linii produkcyjnych wymagają długiego okresu wdrożenia. Studenci poznają $\mathrm{w}$ trakcie praktyk specyfikę przedsiębiorstw i są przygotowywani do realizacji wymienionych zadań. Stąd celem studiów dualnych jest przede wszystkim kształcenie. Jest ono realizowane $\mathrm{w}$ postaci wybranych zajęć laboratoryjnych i projektowych do przedmiotów wykładanych $\mathrm{w}$ Politechnice Poznańskiej, dodatkowych godzin nauki języka obcego oraz specjalistycznych szkoleń związanych ze specyfiką przedsiębiorstw. Kształcenie dualne kończy praca inżynierska, która również jest realizowana na terenie przedsiębiorstw.

Obecnie studia dualne w Politechnice Poznańskiej prowadzone są na Wydziale Elektrycznym (kierunek automatyka i robotyka) oraz na Wydziale Budowy Maszyn i Zarządzania (kierunek mechanika i budowa maszyn) i obejmują studia I stopnia.

\section{Program}

Z przedmiotów kierunkowych i specjalistycznych obecnych $\mathrm{w}$ programie studiów profilu ogólnoakademickiego wyłączono wszystkie te przedmioty i rodzaje zajęć, które ze względu na profile przedsiębiorstw i z pożytkiem dla studentów mogą być realizowane poza Politechnika Poznańską. Rozszerzono również znacznie program praktyk tak, aby studenci jak najwięcej czasu mogli spędzać na terenie przedsiębiorstw.

Studia dualne w Politechnice Poznańskiej trwają 2,5 roku z 3,5 letniego okresu studiów I stopnia. Rozpoczynają się procesem rekrutacji trwającym $w$ trakcie II semestru i dalej przebiegają zgodnie z następującym planem: 
- po II semestrze - dwumiesięczna praktyka letnia;

- w trakcie II roku - jeden dzień w firmach;

- po IV semestrze - dwumiesięczna praktyka letnia;

- w trakcie III roku - dwa dni w firmach;

- po VI semestrze - dwumiesięczna praktyka letnia;

- w trakcie VII semestru - trzy dni w firmach.

Cały cykl studiów dualnych studenci odbywają w tych samych przedsiębiorstwach.

$\mathrm{Na}$ terenie przedsiębiorstw dla kierunku automatyka i robotyka realizowane są następujące przedmioty:

- zautomatyzowane systemy wytwórcze - proj. 30 godz. $30 \operatorname{godz}$.

- sterowniki programowalne i regulatory cyfrowe - lab.

- przedmiot fakultatywny I: podstawy projektowania przemysłowego - wykł. 30 godz., lab. 30 godz.

- projekt przejściowy - proj. 60 godz.

- przedmiot fakultatywny II: sieci i rozproszone systemy sterowania - lab. 30 godz.

- programowanie robotów - lab. 30 godz.

- pracownia dyplomowa (praca dyplomowa)-lab. 30 godz., proj. 90 godz.

Przedmiot fakultatywny podstawy projektowania przemysłowego realizowany jest $\mathrm{w}$ przedsiębiorstwach $\mathrm{w}$ postaci wykładu i projektu, a jego program dostosowany jest do specyfiki i potrzeb przedsiębiorstwa.

Dla kierunku mechanika i budowa maszyn na terenie przedsiębiorstw realizowane są przedmioty:

- obróbka skrawaniem - 15 godz. ćw., 15 godz. lab.

- metrologia techniczna - 15 godz. ćw., 15 godz. lab.

- projektowanie procesów technologicznych-15 godz. proj.

- projekt przejściowy (konstrukcyjny) - 45 godz. proj.

- utrzymanie ruchu i eksploatacja-30 godz. wykł.

- przedmioty fakultatywne - łącznie 60 godz.

Zajęcia na terenie przedsiębiorstw prowadzą pracownicy posiadający odpowiednie kwalifikacje i doświadczenie zawodowe.

Potwierdzeniem kompetencji praktycznych jest egzamin zawodowy zdawany przed komisją Polsko-Niemieckiej Izby 
Przemysłowo-Handlowej w zawodzie monter mechatronik oraz automatyk. Dyplom honorowany jest na terenie UE. Formą przygotowania się do tego egzaminu są dodatkowe zajęcia uzupełniające zagadnienia nie objęte programem studiów w Politechnice Poznańskiej oraz ćwiczenia praktyczne na terenie przedsiębiorstw.

Liczba studentów uczestnicząca $\mathrm{w}$ projekcie studiów dualnych zależy od możliwości późniejszego zatrudnienia w poszczególnych przedsiębiorstwach. Dogodną okolicznością jest budowa przez przedsiębiorstwo Volkswagen w podpoznańskiej Wrześni nowego zakładu produkcyjnego samochodów użytkowych i zapotrzebowanie na inżynierów. Liczba studentów uczestniczących $w$ programie studiów dualnych w kolejnych latach oraz liczba firm jest następująca:

- kierunek automatyka i robotyka

- 2013-2014 - 14 osób (dwie firmy)

- 2014-2015 - 17 osób (trzy firmy)

- 2015-2016 - 16 osób (trzy firmy)

- 2016-2017 - 15 osób (trzy firmy)

- kierunek mechanika i budowa maszyn

- 2014-2015 - 12 osób (trzy firmy)

- 2015-2016 - 21 osób (pięć firm).

\section{Warunki formalne prowadzenia studiów dualnych}

Prowadzenie studiów dualnych było możliwe dzięki wprowadzeniu pojęcia profilu praktycznego, które pojawiło się w treści ustawy z dnia 27 lipca 2005 r. Prawo o szkolnictwie wyższym (Dz. U. 2005, nr 164, poz. 1365 z późniejszymi zmianami). Co prawda program studiów dualnych realizowany w Politechnice Poznańskiej znacznie wykracza poza wymogi ustawy, ale z formalnego punktu widzenia jest to profil praktyczny.

Zasady organizacji studiów dualnych regulują dwie umowy. Pierwsza (bilateralna) zawierana jest pomiędzy Politechniką Poznańską i każdym z partnerów przemysłowych. Określa ogólne 
zasady i obowiązki każdej ze stron. Załącznikami są plany studiów dla danego kierunku i zgody dziekanów na prowadzenie zajęć dydaktycznych przez pracowników zewnętrznych. Zajęcia te finansują przedsiębiorstwa. Druga (trójstronna), obejmuje, oprócz wymienionych partnerów, także uczestniczących w projekcie studentów. Umowa ta określa m.in. zasady wynagradzania oraz zawiera pewne zapisy o charakterze lojalnościowym. Ze względu na to, że podczas całego cyklu studiów dualnych na terenie przedsiębiorstw odbywa się przede wszystkim kształcenie ukierunkowane na potrzeby firm, przedsiębiorcy oczekują że studenci po zakończeniu studiów podejmą pracę w tych przedsiębiorstwach. Treści umów uwzględniają możliwość kontynuowania studiów na II stopniu. Zatrudnienie wszystkich studentów uczestniczących w projekcie nie jest obowiązkiem przedsiębiorstw, jednak względem studentów, którzy taką propozycję otrzymają i odmówią mogą być zastosowane kroki wynikające z zapisów lojalnościowych.

\section{Uczestniczące w projekcie przedsiębiorstwa}

Skład konsorcjum realizującego projekt studiów dualnych uwarunkowane jest przede wszystkim lokalnym rynkiem pracy i obecnością na nim dużych firm niemieckich. Firmy te mają bardzo pozytywne doświadczenia z uczestnictwa w kształceniu dualnym na terenie Niemiec i z dużym zaangażowaniem przystąpiły do działań organizacyjnych oraz samej realizacji kształcenia dualnego w Polsce. Również polskie firmy, które przystąpiły do projektu od II edycji widzą dużą szansę w uczestnictwie w kształceniu studentów w trakcie studiów i „,wychowaniu” przyszłych pracowników, tym bardziej, że inżynierowie, a szczególnie automatycy, są poszukiwani przez firmy z Poznania i okolic.

Obecnie w realizację kształcenia dualnego zaangażowane są następujące przedsiębiorstwa:

- kierunek automatyka i robotyka

- Volkswagen Poznań Sp. z o.o.

- Phoenix Contact Wielkopolska Sp. z o.o. 
- STER Sp. z o.o.

- Beiersdorf Manufacturing Poznań Sp. z o.o.

- kierunek mechanika i budowa maszyn

- Blum Polska Sp. z o.o.

- Phoenix Contact Wielkopolska Sp. z o.o.

- Solaris Bus \& Coach S.A.

- STER Sp. z o.o.

- Zakłady Mechaniczne Kazimieruk Sp. z o.o. Sp.k.

\section{Wnioski i spostrzeżenia uczestników studiów dualnych}

Jako podsumowanie i uzupełnienie przedstawionych rozważań potraktujmy wypowiedzi uczestników studiów dualnych:

Studia dualne to sporo wyrzeczeń i ciężkiej pracy, jednak sukces, który czeka na końcu jest tego wart.

Do programu zgłosiłam się bez większego przekonania, że uda mi się zakwalifikować. Jednak się udało, ponieważ przyszli potencjalni pracodawcy wśród kandydatów nie szukają jedynie osób, które się bardzo dobrze ucza, ale takich, które są komunikatywne, nie boją się wyzwań, a przede wszystkim wiedza, że aby coś osiągnąć trzeba na to zapracować.

Przebieg studiów dualnych wymaga od studentów sporo poświęceń, poza realizacją programu nauczenia $\mathrm{w}$ skróconym czasie (mniejsza ilość dni spędzanych na uczelni) muszą oni chodzić do pracy, gdzie również są im stawiane zadania. W czasie trwania programu uczestnicy odbywają praktykę $\mathrm{w}$ różnych działach przedsiębiorstw. Sytuacja taka pozwala na poznanie specyfiki firm oraz podjęcie $\mathrm{w}$ przyszłości decyzji, w jakim obszarze chciałoby się pracować. Zajęcia $\mathrm{w}$ różnych działach przyczyniają się do zdobywania doświadczenia i wiedzy z różnych dziedzin: od fazy projektowania/modernizacji, poprzez analizę kosztów i ryzyka, kończąc na prowadzeniu projektu.

Podczas trwania studiów dualnych, studenci odbywają szereg szkoleń z kompetencji miękkich i twardych. Jednym z nich było szkolenie dotyczące sztuki prezentacji. Uczyło nie tylko postawy ciała 
przy wystąpieniach, ale także tego jak radzić sobie ze stresem oraz jak dobrze przygotować prezentację, by przekazać wszystkie istotne informacje. Wiedza uzyskana podczas tego szkolenia, pozwoliła studentom na dobre przygotowanie oraz prezentację podczas obrony prac dyplomowych.

Podsumowując mogę powiedzieć, że studia dualne to idealne połączenie wiedzy teoretycznej i praktyki. Poprzez taki układ studenci mogą w praktyce przetestować oraz wykorzystać swoje umiejętności, co pozwala na utrwalenie informacji z zakresu robotyki i automatyki.

Poprzez ten program uczestnicy mogli zrealizować ciekawe tematy prac dyplomowych, które w większości były pracami praktycznymi, a kilka z nich zostało wdrożonych w przedsiębiorstwach, co dla tak młodych osób było ogromnym sukcesem.

Z perspektywy mojej osoby mogę powiedzieć, że dzięki studiom dualnym dostałam pracę $\mathrm{w}$ jednym $\mathrm{z}$ przedsiębiorstw biorących udział w programie. Poprzez sumienną pracę oraz chęć podejmowania nowych wyzwań, dostrzeżono we mnie potencjał i postanowiono dać mi szansę. Dziś jestem pełnoetatowym pracownikiem, realizującym projekty dotyczące modernizacji linii produkcyjnej.

Z tego miejsca chciałabym zachęcić wszystkich studentów do zgłaszania swoich kandydatur do programu studia dualne. Jest to idealna szansa na zdobycie wiedzy praktycznej i teoretycznej, ale także na podjęcie pracy po zakończeniu studiów, bez stresu związanego z chwilowym bezrobociem.

\section{Pierwsza edycja - doświadczenia}

Na początku 2016 r. zakończyła się I edycja studiów dualnych. Wszyscy uczestniczący $\mathrm{w}$ projekcie studenci zostali zatrudnieni we współpracujących przedsiębiorstwach. Potwierdzeniem, że założenia projektu zostały zrealizowane są tematy prac inżynierskich realizowanych w przedsiębiorstwach:

- Koncepcja zwiększenia wydajności linii produkcyjnej lewych drzwi przesuwnych VW Caddy. 
- Diagnostyka robotów przemysłowych na przykładzie robota Fanuc.

- Projekt $i$ wykonanie stanowiska pokazowo-edukacyjnego z robotem Mitsubishi i elementami peryferyjnymi.

- Budowa i oprogramowanie wielorobotowego obróbczego stanowiska szkoleniowego.

- Koncepcja i weryfikacja symulacyjna robotyzacji stanowiska klejenia poszyć bocznych.

- Budowa stanowiska testowego komunikacji bezprzewodowej sieci PROFINET.

Efektem ubocznym studiów dualnych jest fakt, że żaden ze studentów nie kontynuuje studiów stacjonarnych na II stopniu, ponieważ zostali zatrudnieni w pełnym wymiarze czasu pracy. Deklarują natomiast chęć kontynuowania studiów w trybie niestacjonarnym, do czego mobilizują ich również pracodawcy, deklarując pomoc finansową. 